\title{
PROGRAM SERVICE RECOVERY UNTUK PENCIPTAAN KEPUASAN PELANGGAN DI ANGKUTAN KERETA API DAERAH OPERASI 2 BANDUNG
}

\author{
Fitri Lestari
}

STIE EKUITAS

fitri.lestari@ekuitas.ac.id

\begin{abstract}
The development modes of transportation in Indonesia led to competition in the various modes such as by land; sea and air were increasing. Railway is one mode of transportation, especially as the most dominated by the passenger in Bandung. Due to higher competition pattern, efforts were made to improve passenger satisfaction. Various complaints can occur, and will increase if not addressed promptly so that the company should seek to restore service (service recovery) that passengers are satisfied. This study was conducted to determine how the implementation of the program service recovery Argo Gede Train, perceived satisfaction of passengers and how much influence the program service recovery on customer satisfaction.

The object of this research was Argo Gede Train passenger route Bandung-Jakarta. The independent variable in this study was a service recovery program (X), and the dependent variable was customer satisfaction $(Y)$. The type of research was descriptive verification, through explanatory survey method with simple random sampling technique, and 100 respondents were analyzed by linear regression analysis. The data used in this study are primary data and secondary data, with data collection through interviews, direct observations, and questionnaires' research, and literature studies. The results showed in the service recovery program, has improved the accuracy of the biggest scores. The results showed that the service recovery program has the effect of $47.80 \%$ on customer satisfaction to note that the service recovery program has a significant impact on customer satisfaction.
\end{abstract}

Keywords: Service Recovery, Customer Satisfaction

\section{PENDAHULUAN}

Pada era globalisasi ini, mengakibatkan setiap Negara berkembang dalam segala bidang. Salah satunya yaitu dalam moda transportasi, dimana persaingan di berbagai moda transportasi baik darat, laut maupun udara semakin meningkat.

Permasalahan mendasar yang dihadapi moda transportasi di Indonesia selama ini yang juga masih dirasakan pada kurun waktu tahun 2004 sampai dengan 2009; terutama, adalah masih kurang memadainya sarana dan prasarana transportasi jika dibandingkan dengan permintaan akan pelayanan jasa transportasi. Penyediaan, kepemilikan, pengoperasian dan pemeliharaan sarana dan prasarana transportasi selama ini masih didominasi oleh Pemerintah dan BUMN, yang tarif pelayanannya cenderung di bawah harga (underpriced). Akibatnya, kinerja dan pelayanan moda transportasi di Indonesia pada umumnya masih sangat buruk.

Pertumbuhan sektor transportasi sebelum krisis ekonomi berkisar 7\%, kemudian menurun sangat tajam menjadi sekitar $1,2 \%$ pada tahun 1997. pada tahun 1999/2000 tingkat pertumbuhan sektor transportasi mencapai titik 
nadir yaitu sekitar $0,8 \%$. Secara umum untuk sub sektor transportasi Kereta Api, menunjukkan tingkat pertumbuhan yang paling baik dibandingkan dengan moda lainnya. Transportasi jalan merupakan moda yang paling terpengaruh oleh krisis ekonomi.

Pada tahun 2009 pertumbuhan permintaan jasa terhadap angkutan jalan meningkat 3,8\% per tahun dengan total jumlah penumpang sebanyak 530.486 ribu penumpang atau $83,9 \%$ dari total permintaan terhadap transportasi yang berjumlah 634.660 ribu penumpang.

Permintaan terhadap angkutan Kereta Api dan Angkutan Sungai Danau dan Penyebrangan mengalami peningkatan yang cukup pesat sebagaimana disajikan pada Gambar 1

Sumber : Departemen Perhubungan 2009

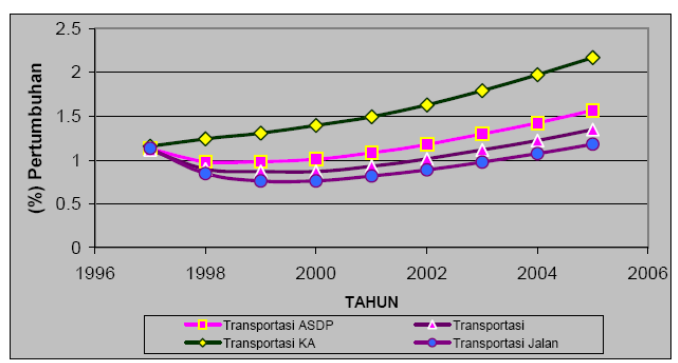

GAMBAR 1

TINGKAT PERTUMBUHAN MODA TRANSPORTASI DARAT

TABEL 1

TOTAL PERMINTAAN ANGKUTAN

\begin{tabular}{|c|c|c|c|c|c|}
\hline \multirow[t]{2}{*}{ Moda Transportasi } & \multicolumn{2}{|c|}{$\begin{array}{l}\text { Penumpang } \\
\text { Tahun } 1998 \\
\end{array}$} & \multicolumn{2}{|c|}{$\begin{array}{c}\text { Penumpang } \\
\text { Tahun } 2009 \\
\end{array}$} & \multirow{2}{*}{$\begin{array}{l}\text { Pertumbuhan } \\
\text { per tahun } \\
1998 \text {-2009 }\end{array}$} \\
\hline & Trips (.000) & Persentase & Trips (.000) & Persentase & \\
\hline Angkutan Jalan & 279,444 & $92,2 \%$ & 461.961 & $93,0 \%$ & $4,7 \%$ \\
\hline Angkutan Kereta Api & 1.918 & $0.6 \%$ & 1.918 & $0,4 \%$ & $0,00 \%$ \\
\hline Angkutan SDP & 32 & $0,0 \%$ & 32 & $0,0 \%$ & $0,0 \%$ \\
\hline Angkutan Udara & 21.650 & $7,1 \%$ & 32.320 & $6,5 \%$ & $3,7 \%$ \\
\hline Angkutan Laut & 153 & $0,1 \%$ & 276 & $0,1 \%$ & $5,5 \%$ \\
\hline TOTAL & 303.197 & $100 \%$ & 496.507 & $100 \%$ & $4,6 \%$ \\
\hline
\end{tabular}

Sumber : Departemen Perhubungan 2009

Permintaan transportasi darat diseluruh wilayah tanah air secara umum mempunyai tingkat pertumbuhan antara $3,2 \%-4,2 \%$ per tahun. Khususnya di Bandung perkembangan moda transportasi, mengalami persaingan yang cepat ini mengharuskan perusahaan lebih kreatif dalam mempertahankan konsumennya. Moda transportasi di Bandung di dominasi oleh PT. Kereta Api, masyarakat lebih banyak menggunakan jasa Kereta Api dibandingkan menggunakan jasa tranportasi lainnya. Kereta Api menjadi pilihan prioritas bagi masyarakat
Bandung. Tetapi setelah dibukanya Tol Cipularang April 2005, penumpang Kereta Api rute Bandung-Jakarta sangat menurun dibandingkan tahun-tahun sebelumnya yang terus-menerus mengalami peningkatan.

Tol Cipularang membuka peluang rute Bandung-Jakarta untuk bis dan travel, sehingga banyak penumpang yang lebih memilih menggunakan bis dan travel. Hal ini disebabkan oleh, diantaranya waktu tempuh jarak BandungJakarta yang lebih cepat menggunakan bis dan travel. Harga yang relatif murah dibandingkan menggunakan kereta api, pelayanan jasa yang prima terhadap pelanggan. Hal ini dapat diketahui dari pra penelitian 2009 bahwa tingkat kapuasan penumpang Kereta Api jika dilihat berdasarkan gender, pria cenderung merasa tidak puas dibandingkan dengan wanita. Persentase pria yang tidak puas adalah sebesar $32 \%$ dari total pria secara keseluruhan. Sebaliknya, persentase yang puas pada wanita sebesar $9 \%$, penumpang pria lebih merasa tidak puas dibandingkan dengan wanita.

Pada pelayanan angkutan kereta api, perkembangan perkeretaapian sangat lamban, bahkan mengalami stagnasi, kalau tidak bisa dikatakan mengalami penurunan atau semakin memburuk, baik dari sisi pemberian pelayanan, keselamatan penumpang maupun dari sisi pengembangan jaringan prasarana kereta api. Hal itu diindikasikan dengan meningkatnya jumlah kecelakaan kereta api, seperti yang terjadi akhir-akhir ini, di antaranya kecelakaan Kereta Api batu bara rangkaian panjang (Babaranjang) di lintas Tanjung Enim-Tarahan, kecelakaan antara kereta api dan kendaraan angkutan jalan di perlintasan sebidang Kereta Api, serta kecelakaan antar-Kereta Api Listrik (KRL) dan kecelakaan Kereta Api penumpang kelas ekonomi dengan Kereta Api pengangkut batu bara.

Salah satu penyebab utama menurunnya kinerja perkeretaapian adalah rendahnya daya saing Kereta Api terhadap moda angkutan lain, yang diakibatkan oleh rendahnya kualitas prasarana dan sarana, pelayanan penumpang, Sumber Daya Manusia ataupun teknologi yang digunakan, serta kondisi internal manajemen PT. Kereta Api yang kurang efisien, dan juga tidak didukung oleh regulasi dan kelembagaan yang kondusif, efisien, dan terpadu. Selain itu, terdapat masalah dalam pengelolaan kereta api, yaitu saat ini semua kegiatan yang berkaitan 
dengan pengelolaan perkeretaapian dilakukan secara terpusat oleh pemerintah pusat, serta pengelolaannya, baik prasarana maupun sarana dimonopoli oleh satu Badan Usaha Milik Negara (BUMN), yaitu PT. Kereta Api, tanpa melibatkan peran Pemerintah Daerah ataupun partisipasi pihak swasta. Akibatnya, pertumbuhan dan perkembangan pelayanan kereta api sangat lamban.

Berdasarkan rata-rata kelambatan Kereta Api penumpang berangkat, tahun 2008 adalah2 menit dan 2009 adalah 5 menit. Terjadi peningkatan kelambatan di tahun 2009. Kelambatan Kereta Api umumnya terjadi akibat adanya pengurangan kecepatan Kereta Api, karena pada bagian jalan Kereta Api tertentu sedang ada pelaksanaan pekerjaan perbaikan pada komponen jalan rel, baik berupa penggantian rel, bantalan, maupun penambahan balas, sehingga Kereta Api harus berjalan perlahan dan berpengaruh terhadap total waktu tempuh.

Kecelakaan Kereta Api dari data klasifikasi terjadi penurunan dari tahun 2007 sampai tahun 2009. Data korban yang meninggal dunia mengalami peningkatan, sedangkan data korban luka ringan/luka berat terjadi penurunan dari tahun 2007 sampai tahun 2009. Itu artinya bahwa keselamatan merupakan faktor yang paling utama.

Menurut Departemen Perhubungan dalam transportasi "keselamatan itu harus diletakkan paling utama", jadi ada satu standar minimum yang tidak boleh dikurangi yaitu faktor keselamatan. Seperti kenyamanan, itu merupakan yang berikutnya. Orang naik angkutan umum itu persepsinya "saya harus selamat". Untuk memenuhi kepuasan pelanggan, pelanggan memilih pelayanan jasa yang terbaik dalam menggunakan moda transportasi.

Perusahaan jasa harus dapat mengetengahkan secara konsisten jasa yang berkualitas lebih tinggi daripada pesaingnya. Pelanggan (konsumen) memilih penyedia jasa dengan membandingkan pelayanan yang dirasakan (preceived services) dengan yang diharapkan (expected services). Jika pelayanan yang dirasakan berada dibawah yang diharapkan, maka timbul suatu ketidakpuasan pelanggan, rasa kepercayaan pelanggan terhadap penyedia jasa menjadi berkurang (hilang), pendapatan perusahaan menurun dan akhirnya membahayakan kelangsungan hidup perusahaan. Sebaliknya jika pelayanan yang dirasakan sama atau lebih besar yang diharapkan, maka pelanggan merasa puas. Mereka akan menggunakan kembali jasa tersebut dan memberitahukan kepada yang lain, sehingga menjadi alat promosi yang efektif dan kelangsungan hidup perusahaan menjadi lebih terjamin. Oleh karena itu penyedia jasa harus dapat mengidentifikasi keinginan konsumen dalam hal kualitas pelayanan secara umum maupun khusus.

Strategi produk/jasa yang dilakukan PT. Kereta Api, dengan meluncurkan produk baru kereta api rute Bandung-Jakarta yaitu Argo Gede. Dengan begitu pelanggan dapat memilih produk/jasa baru yang diberikan oleh PT. Kereta Api untuk memuaskan keinginan pelanggan dan untuk memproduksi produk/jasa bermutu tinggi serta harga bersaing.

PT. Kereta Api melakukan strategi promosi dengan penyebaran brosur yang di update setiap satu bulan sekali untuk mendapatkan informasi terbaru. Promosi pun dilakukan melalui media cetak seperti koran, media elektronik internet online, yang langsung dapat memesan tiket, juga pemesanan tiket dapat melalui kantor pos, reservasi dan agen.

Strategi-strategi di atas yang dilakukan oleh PT. Kereta Api merupakan, service recovey yaitu strategi untuk memenuhi kepuasan pelanggan PT. Kereta Api.

Berdasarkan latar belakang penelitian di atas maka dirumuskan masalah pokok dalam penelitian ini, yaitu:

1. Bagaimana pelaksanaan program service recovery pada Kereta Api Argo Gede.

2. Bagaimana tanggapan penumpang terhadap pelaksanaan program service recovery pada Kereta Api Argo Gede.

3. Sejauhmana pengaruh program service recovery terhadap kepuasan pelanggan pada Kereta Api Argo Gede.

\section{KERANGKA PEMIKIRAN}

Bauran pemasaran jasa merupakan alat yang digunakan oleh jasa angkutan dalam membentuk karakteristik jasa yang ditawarkan kepada penumpang. Bauran pemasaran jasa mencakup product, price, place, promotion, people, process, physical evidence dan customer service. Zeithaml dan Bitner dalam buku Ratih 
Hurriyati (2009:49) dan Rambat Lupiyoadi dan A. Hamdani (2008:81)

Bauran pemasaran jasa sebagai alat yang digunakan jasa angkutan jika tidak dapat dikendalikan dengan baik, maka akan mengakibatkan kegagalan pelayanan (service failure). Kegagalan pelayanan tersebut harus diperbaiki, supaya penumpang merasa puas dan tidak berpindah ke pesaing yaitu dengan melakukan strategi kepuasan pelanggan, di antaranya: strategi manajemen ekspektasi pelanggan, relationship marketing \& management, aftermarketing, strategi retensi pelanggan, superior customer service, technology infusion strategy, sistem penanganan komplain secara efektif, dan service recovery.

Service recovery merupakan tindakan yang dilakukan penyedia jasa untuk menyelesaikan masalah yang diakibatkan terjadinya kegagalan jasa dan meningkatkan kepuasan pelanggan (penumpang). Pemulihan layanan terhadap kegagalan jasa yang timbul yang ditujukan untuk mengembalikan kepuasan pelangan atas kekecewaan yang di alami dan untuk mengembalikan kepercayaan dari pelanggan agar tetap membeli kembali produk yang dilakukan sebaik dan secepat mungkin.

Kurtz and Boone dalam Contemporary Marketing Plus (1995), customer satisfaction is the ability of goods or services to meet or exceed buyer need and expectations. Jika saat pelanggan membeli dan menggunakan suatu produk, dan mampu memenuhi bahkan melampaui kebutuhan dan harapannya, maka akan terjadi kepuasan.

Berdasarkan penjelasan teori di atas, dapat diketahui bahwa service recovery dilakukan untuk memperbaiki kegagalan pelayanan yang bersumber dari bauran pemasaran jasa yang kurang terkendali, sehingga dapat meningkatkan kepuasan penumpang.

Bauran pemasaran jasa sebagai alat bagi pemasar untuk membentuk karakteristik jasa jika kurang terkendali akan menyebabkan kegagalan jasa yang dapat membuat penumpang kecewa, maka dari itu perusahaan melakukan strategi kepuasan yaitu program service recovery, dimana strategi yang dilakukan diantaranya meningkatkan ketelitian, mendengarkan keluhan, mengklarifikasikan bagaimana staf dapat bekerja apabila kata maaf tidak cukup, belajar dari kesalahan, menjadi proaktif, dan meningkatkan kinerja. Strategi tersebut dapat menciptakan nilai yang diberikan perusahaan yang berdampak pada kepuasan.

\section{METODE PENELITIAN}

Berdasarkan jenisnya, maka penelitian ini bersifat deskriptif dan verifikatif. Melalui penelitian deskriptif akan diperoleh gambaran mengenai service recovery $(\mathrm{X})$ yang terdiri atas meningkatkan ketelitian, mendengarkan keluhan, mengklarifikasikan bagaimana staf dapat bekerja apabila kata maaf tidak cukup, belajar dari kesalahan, menjadi proaktif, dan meningkatkan kinerja dan kepuasan pelanggan (Y) di kereta api argo gede rute BandungJakarta.

Sifat verifikatif pada dasarnya ingin menguji kebenaran dari suatu hipotesis yang dilaksanakan melalui pengumpulan data di lapangan, di mana dalam penelitian ini akan diuji seberapa besar pengaruh service recovery terhadap kepuasan pelanggan kereta api argo gede rute Bandung-Jakarta.

Berdasarkan jenis penelitiannya, yakni deskriptif dan verifikatif yang dilaksanakan melalui pengumpulan data di lapangan, maka metode penelitian yang akan digunakan adalah metode explanatory survey. Survei informasi dari sebagian populasi (sampel responden) dikumpulkan langsung ditempat kejadian secara empirik, dengan tujuan untuk mengetahui pendapat dari sebagian populasi terhadap objek yang sedang diteliti.

\section{HASIL DAN PEMBAHASAN Pelayanan Kereta Api}

1. Pelayanan Re-Launching :

Pelayanan Ticketing, merupakan proses awal dari pelayanan untuk mendapatkan tiket, di mana pelanggan dapat melakukan pembelian tiket langsung di loket, agen dan reservasi atau pemesanan tiket melalui ATM/online dan call centre. Pelanggan yang memesan tiket melalui ATM/online dan call centre, maka pelanggan harus menukarkan bukti pembelian yang berupa struk pembelian di loket tiket dengan tiket keberangkatan.

Pelayanan cek petugas portir dan greeter, merupakan proses lanjutan dari pelayanan ticketing, di mana pelanggan melakukan proses pelaporan pelanggan dan tiket. Pada proses ini pelanggan harus menunjukkan tiket kepada petugas portir untuk memperoleh informasi keberangkatan kereta yang dituju. 
Boarding Position, pramugari/pramugara on position. Pramugari/pramugara memberikan informasi lokasi kereta api dan tempat duduk pelanggan sesuai dengan tiket yang dimiliki pelanggan.

2. Pelayanan di atas Kereta Api

Pelayanan di atas kereta api meliputi pemberian informasi, yaitu:

1. Persiapan menjelang keberangkatan

a) Lima menit sebelum keberangkatan : Anouncer mengumumkan keberangkatan kereta api dan mempersilahkan pengantar untuk turun dari kereta api.

b) Lima menit setelah keberangkatan : Anouncer memperkenalkan Manager On Train, Captain crew dan crew yang bertugas.

c) Lima menit menjelang memasuki terowong Sasaksaat dan Jembatan Cisomang. Anouncer menyampaikan informasi terkait dengan lokasi tersebut.

2. Pelayanan dalam perjalanan

a) On Train Crew (OTC) menjaga kebersihan toilet dan standby di bordes.

b) On Train Crew (OTC) membersihkan rangkaian setiap 30 menit.

c) Polisi Khusus Kereta Api (POLSUSKA) standby di bordes dan mobile di Kereta Api setiap 30 menit.

d) Makanan dan minuman disajikan dalam kondisi tertutup dan hangat.

e) Para crew menjaga etika pelayanan : ramah, tersenyum, sopan dan tegas, membantu, mencatat pesanan, menyajikan makan atau minum sesuai pesanan dan cepat maksimal 30 menit dari waktu pemesanan.

3. Persiapan menjelang tiba di stasiun tujuan Lima menit menjelang stasiun tujuan : Anouncer menyampaikan informasi kepada pelanggan untuk mempersiapkan diri.

4. Setiba di stasiun tujuan

Manager On Duty menyerahkan laporan keluhan pelanggan KSB Bandung.

\section{Program Service Recovery}

Pemulihan layanan terhadap kegagalan jasa yang timbul yang ditujukan untuk mengembalikan kepuasan pelangan atas kekecewaan yang di alami dan untuk mengembalikan kepercayaan dari pelanggan agar tetap membeli kembali produk yang dilakukan sebaik dan secepat mungkin. Gail Scott dalam Healthcare Executive (2009), meliputi :

1. Meningkatkan ketelitian : perubahan diawali dengan ketelitian yang berarti setiap petugas mesti memahami mengapa pemulihan jasa begitu penting sekali. Banyak konsumen menderita di dalam keterisoliran. Dari data National Consumer Research Organization menyatakan :

a) Hanya sekitar 15 persen planggan akan kembali jika mereka mengalami kualitas pelayanan yang buruk.

b) 60 persen pelanggan akan kembali jika mereka mengalami kualitas pelayanan yang buruk akan tetapi dapat memberikan suara sebagai suatu keluhan.

c) 80 persen pelanggan akan kembali jika mereka mempunyai kualitas pelayanan yang buruk akan tetapi permasalahannya dapat dipecahkan.

2. Mendengarkan keluhan : sangat penting sekali mendengarkan keluhan konsumen tujuannya adalah untuk mengurangi keluhan. Setiap perusahaan ingin mengurangi jumlah masalah dan setiap perusahaan dapat memberikan kepuasan dengan jasa dan pelayanannya kepada setiap pelanggan yang merasakannya. Agar hal ini terlaksana maka perlu untuk bertanya dan lebih dekat lagi dengan para konsumen. Pertanyaan-pertanyaan secara langsung dan termuka dapat membantu kita memahami persepsi proses pelayanan tersebut.

Model "act with TACT" untuk merespon keluhan-keluhan umum :

$\mathrm{T}=$ Take ownership

$\mathrm{A}=$ Acknowldge and aplogize

$\mathrm{C}=$ Corect and communicate

$\mathrm{T}=$ Thank, track, trend and learn

3. Mengklarifikasikan bagaimana staf dapat bekerja apabila kata maaf tidak cukup : apabila kata maaf tidak cukup, perusahaan memberikan cara kepada staf untuk menyesuaikannya.

4. Belajar dari Kesalahan : track, trend and learn belajar dari pengalaman. Keluhan pelanggan dapat memberikan evaluasi 
dengan cara meningkatkan pemulihan jasa. Agar tidak mengulangi kesalahan yang sama harus mencari solusi bagaimana memberikan bantuan kepada pelanggan dalam menghadapi masalah-masalahnya.

5. Menjadi proaktif : melakukan segala sesuatu yang dapat dilakukan untuk mencegah masalah dan kesalahan yang telah terjadi. Dengan mengetahui kesalahan yang terjadi, maka harus bertindak secara proaktif.

6. Meningkatkan kinerja : kesalahan adalah sebuah kesempatan untuk belajar dan berkembang. Berusaha mengumpulkan keberanian untuk megucapkan "maaf" dan menggunakan kata maaf itu untuk membantu orang-orang dalam melaksanakan service recovery. Dengan melakukan hal yang positif seperti memperbaiki secara keseluruhan dengan terorganisir dan bertahap. Dengan bekerja keras memfokuskan pada kepuasan dan melihat beberapa masalah itu sebagai kesempatan untuk menambah nilai dalam meningkatkan kinerja.

\section{DESKRIPSI PELAKSANAAN PROGRAM SERVICE RECOVERY}

\section{Meningkatkan ketelitian}

Merupakan salah satu strategi perusahaan untuk meningkatkan kinerjanya. Indikator yang pertama bahwa skor yang paling tinggi dari tanggapan pelanggan terhadap meningkatkan ketelitian yang diberikan PT. Kereta Api yaitu pada item ketelitian pelayanan dalam menyajikan makanan dan minuman dengan skor 355 , yang terdiri dari $4 \%$ pelanggan menyatakan tidak teliti, $45 \%$ pelanggan menyatakan cukup teliti, $43 \%$ pelanggan menyatakan teliti, dan $8 \%$ menyatakan sangat teliti. Perbandingan pelanggan yang menyatakan cukup teliti dan teliti pada item ketelitian pelayanan dalam menyajikan makanan dan minuman, tidak terlalu jauh. Pelanggan menganggap bahwa ketelitian pelayanan dalam menyajikan makanan dan minuman dilakukan petugas dengan teliti.

Sedangkan skor terendah dari meningkatkan ketelitian dalam program service recovery Kereta Api Argo Gede dengan skor 294 yaitu pada item ketelitian petugas dalam menangani keamanan dalam kereta. Hal ini disebabkan petugas masih dianggap kurang siap dalam menangani keamanan dalam kereta.

\section{Mendengarkan keluhan}

Mendengarkan keluhan dalam program service recovery yaitu mendengarkan penjelasan atas kegagalan pelayanan yang diberikan kepada pelanggan.

Hasil tersebut memperlihatkan meningkatkan ketelitian dalam program service recovery Kereta Api Argo Gede dengan dua item pertanyaan. Skor terendah yaitu pada item kecepatan petugas dalam menangani keluhan, dengan skor 351 yang terdiri dari 3\% pelanggan menyatakan sangat tidak cepat, $4 \%$ pelanggan menyatakan tidak cepat, $42 \%$ pelanggan menyatakan cukup cepat, $41 \%$ pelanggan menyatakan cepat, dan $10 \%$ pelanggan menyatakan sangat cepat. Hal ini dapat disebabkan karena petugas masih dianggap kurang cepat dalam menangani keluhan pelanggan.

Sedangkan skor tertinggi yaitu pada item ketepatan petugas dalam menangani keluhan pelanggan, dengan skor 366 yang terdiri dari $4 \%$ pelanggan menyatakan tidak tepat, $42 \%$ pelanggan menyatakan cukup tepat, 38\% pelanggan menyatakan tepat, dan $16 \%$ pelanggan menyatakan sangat tepat. Hal ini dapat dipahami karena keluhan pelanggan sangat penting. Maka dari itu, petugas sangat tepat dalam menangani keluhan pelanggan.

\section{Mengklarifikasikan bagaimana Staf dapat} Bekerja apabila Kata Maaf Tidak Cukup

Mengklarifikasikan bagaimana staf dapat bekerja apabila kata maaf tidak cukup dalam program service recovery yaitu memberikan penjelasan atas kegagalan pelayanan yang diberikan PT. Kereta Api.

Mengklarifikasikan bagaimana staf dapat bekerja apabila kata maaf tidak cukup dalam program service recovery Kereta Api Argo Gede. Hasil penilaian pelanggan item pertanyaan kesediaan memberikan jaminan tidak akan terjadi kesalahan dalam pelayanan dengan skor 331, setengah dari jumlah responden yaitu $56 \%$ pelanggan menyatakan cukup bersedia. Hal ini dikarenakan bahwa responden menilai kesediaan petugas yang diberikan dirasakan bersedia dan hanya sebagian yang merasakan petugas belum bersedia dalam memberikan jaminan tidak akan terjadi kesalahan dalam pelayanan.

\section{Belajar dari Kesalahan}

Belajar dari kesalahan dalam program service recovery yaitu memberikan penjelasan 
atas kegagalan pelayanan yang diberikan PT. Kereta Api. Hasil dari penilaian pelanggan terhadap item pertanyaan belajar dari kesalahan dalam program service recovery Kereta Api Argo Gede skor 351 , terdiri dari $1 \%$ pelanggan menyatakan sangat tidak bersedia, 5\% pelanggan menyatakan tidak bersedia, $45 \%$ pelanggan menyatakan cukup bersedia, $40 \%$ pelanggan menyatakan bersedia dan $9 \%$ pelanggan menyatakan sangat bersedia. Maka dari itu, $71,5 \%(9 \%+40 \%+(45: 2))$ pelanggan memberikan penilaian bersedia terhadap kesediaan pelayanan petugas dalam memperbaiki kesalahan. Hal ini dikarenakan bahwa responden menilai kesediaan petugas yang diberikan kepada pelanggan dirasakan bersedia dan hanya sebagian yang merasakan petugas belum bersedia dalam memperbaiki kesalahan.

\section{Menjadi Proaktif}

Menjadi proaktif dalam pelaksanaan program service recovery Kereta Api Argo Gede adalah suatu strategi kereta api dalam meningkatkan pelayanannya.

Hasil tersebut memperlihatkan menjadi proaktif dalam program service recovery Kereta Api Argo Gede. Skor terendah yaitu pada item proses pengalihan/pemindahan penumpang ke moda transportasi lain, jika terjadi rintang jalan, dengan skor 321 yang terdiri dari 5\% pelanggan menyatakan sangat tidak sesuai, $19 \%$ pelanggan menyatakan tidak sesuai, $37 \%$ pelanggan menyatakan cukup sesuai, $28 \%$ pelanggan menyatakan sesuai dan $11 \%$ pelanggan menyatakan sangat sesuai. Hal ini dapat disebabkan karena tidak sesuai dalam pemindahan penumpang ke moda transportasi lain. Dan tidak antisipasi apabila terjadi rintang jalan.

Sedangkan skor tertinggi yaitu pada item kesediaan petugas memberikan informasi keterlambatan kedatangan kereta api, dengan skor 364 yang terdiri dari $5 \%$ pelanggan menyatakan sangat tidak bersedia, $7 \%$ pelanggan menyatakan tidak bersedia, 30\% pelanggan menyatakan cukup bersedia, 35\% pelanggan menyatakan bersedia, dan $23 \%$ pelanggan menyatakan sangat bersedia. Hal ini dapat dipahami karena petugas yang kurang proaktif dalam memberikan informasi keterlambatan kedatangan kereta api, sehingga membuat pelanggan menunggu lama kedatangan kereta api.

\section{Meningkatkan Kinerja}

Meningkatkan kinerja dalam pelaksanaan program service recovery Kereta Api Argo Gede adalah suatu strategi kereta api dalam meningkatkan pelayanannya. Hasilnya memperlihatkan skor terendah yaitu pada item kemampuan petugas menjelaskan informasi prosedur perjalanan kereta api, dengan skor 329 yang terdiri dari $2 \%$ pelanggan menyatakan sangat tidak mampu, $17 \%$ pelanggan menyatakan tidak mampu, $44 \%$ pelanggan menyatakan cukup mampu, $24 \%$ pelanggan menyatakan mampu dan $13 \%$ pelanggan menyatakan sangat mampu. Hal ini dapat disebabkan karena kurangnya kinerja petugas dalam menjelaskan informasi perjalanan kereta api.

Sedangkan skor tertinggi yaitu pada item kemampuan petugas dalam melayani pemesanan tiket/reservasi, dengan skor 363 yang terdiri dari $1 \%$ pelanggan menyatakan sangat tidak mampu, $8 \%$ pelanggan menyatakan tidak mampu, $35 \%$ pelanggan menyatakan cukup mampu, 39\% pelanggan menyatakan mampu, dan $17 \%$ pelanggan menyatakan sangat mampu. Hal ini dapat dipahami karena pelanggan menganggap bahwa petugas mampu melayani kemudahan pemesanan tiket/reservasi. Pemesanan dapat dengan mudah dengan melalui loket langsung, pemesanan/reservasi, call centre, agen dan ATM/online.

Berdasarkan hasil pengumpulan data, diperoleh tanggapan pelanggan mengenai pelaksanaan program service recovery Kereta Api Argo Gede adalah sebagai berikut:

Menunjukkan bahwa subvariabel yang memperoleh skor tertinggi adalah subvariabel meningkatkan ketelitian dengan perolehan skor sebesar 2573 atau $34,87 \%$. Tanggapan pelanggan yang terendah adalah pada subvariabel mengklarifikasikan bagaimana staf dapat bekerja apabila kata maaf tidak cukup dengan skor 331 atau 4,49\%. Meningkatkan ketelitian menjadi subvariabel dengan skor tertinggi dikarenakan pelanggan dapat memahami dengan jelas mengenai petugas yang teliti dalam memberikan pelayanan kepada pelanggan.

\section{Kepuasan Pelanggan}

Untuk menentukan kebutuhan dan keinginan pelanggan yang akan dipuaskan bukanlah hal yang mudah, hal ini disebabkan karena kebutuhan dan keinginan pelanggan selalu 
mengalami perubahan dari waktu ke waktu, jika pelanggan merasa puas, maka ada kecenderungan untuk melakukan pembelian ulang.

Kurtz and Boone dalam Jurnal Contemporary Marketing Plus (1995), customer satisfaction is the ability of goods or services to meet or exceed buyer need and expectations. Jika saat pelanggan membeli dan menggunakan suatu produk, dan mampu memenuhi bahkan melampaui kebutuhan dan harapannya, maka akan terjadi kepuasan. Westbrook $\& t$ Reilly dalam Fandy Tjiptono (2008:349), Kepuasan pelanggan merupakan respons emosional terhadap pengalaman-pengalaman berkaitan dengan produk atau jasa tertentu yang dibeli, gerai ritel, atau bahkan pola perilaku (seperti perilaku berbelanja dan perilaku pembeli), serta pasar secara keseluruhan.

Hanan dan Karp dalam Customer Satisfication: How to Maximize Measure and Market Your Company's (1989) menyatakan bahwa didalam mengevaluasi kepuasan pelanggan terhadap suatu produk selalu mengacu pada atribut-atribut pembentuk kepuasan, dikenal dengan istilah The Big Eight. Sehingga kepuasan pelanggan dapat tercapai apabila sebuah produk atau jasa memenuhi atau melampaui harapan pelanggan, biasanya pelanggan merasa puas. Namun demikian pelanggan juga tidak serta merta menolak pelayanan yang diberikan oleh perusahaan, pelanggan memiliki batas toleransi terhadap pelayanan yang diberikan oleh perusahaan. Semakin dekat harapan 'pelayanan yang diharapkan dengan 'pelayanan minimun yang dapat diterima', semakin besar pula kemungkinan tercapainya kepuasan.

Freddy Rangkuti (2006:23) berpendapat bahwa "Kepuasan pelanggan mencakup perbedaan antara tingkat kepentingan dan kinerja atau hasil yang dirasakan”.

Menurut Kotler dan Amstrong (2007:10) Kepuasan pelanggan merupakan tingkatan di mana anggapan kinerja (perceived performance) produk akan sesuai dengan harapan seorang pembeli. Bila kinerja produk jauh lebih rendah dibandingkan harapan pelanggan, pembelinya tidak puas. Bila kinerja sesuai dengan harapan, pembelinya merasa puas atau sangat gembira.
Subvariabel yang memperoleh skor tertinggi adalah subvariabel tingkat harapan dengan perolehan skor terbesar 3160 atau $54,87 \%$. Dikarenakan pelanggan memiliki tingkat harapan yang tinggi terhadap kinerja pelayanan kereta api argo gede.

Hasil kepuasan pelanggan program service recovery sebesar 0,82. Yaitu tingkat kinerja dibagi tingkat harapan. Dikarenakan pelanggan memiliki tingkat harapan yang tinggi terhadap kinerja pelayanan Kereta Api Argo Gede.

Distirbusi frekuensi kepuasan pelanggan kereta api argo gede berada pada interval 0,80 $1,62,5 \%$ yaitu sangat puas dan sisanya $37,5 \%$ pada interval $0,60-0,79$ puas. Dapat disimpulkan bahwa kepuasan pelanggan kereta api argo gede sangat puas.

\section{HASIL PENGUJIAN HIPOTESIS}

Pengujian hipotesis dilakukan untuk menguji besarnya pengaruh program service recovery (X) terhadap keputusan pembelian (Y). Maka dilakukan penghitungan regresi linier sederhana dengan menggunkan aplikasi software SPSS (Statistical Product for Service Solution) 17,0 dan dibantu software microsoft excel.

\section{Analisis Korelasi}

Hasil dari pengolahan data untuk mengetahui korelasi atau hubungan antara program service recovery dengan kepuasan pelanggan adalah 0,691 artinya terdapat hubungan yang kuat antara variabel program service recovery dan variabel kepuasan pelanggan, berdasarkan interpretasi koefisien korelasi nilai $r \quad(0,60$ $0,799)$. Nilai $p$-value pada kolom sig. (1-tailed) $0,000<0,05$ level of significant $(\alpha)$ berarti $\mathrm{Ha}$ diterima dan Ho ditolak. Artinya, program service recovery berkorelasi dengan kepuasan pelanggan. Secara spesifik, jika program service recovery mengalami kenaikan maka kepuasan pelanggan akan mengalami kenaikan, atau jika program service recovery mengalami penurunan maka kepuasan pelanggan akan mengalami penurunan.

\section{Analisis Regresi}

Untuk membuktikan hipotesis, yaitu adanya pengaruh signifikan antara program service recovery terhadap tingkat kepuasan pelanggan.

Berdasarkan pengolahan data secara regresi linier sederhana, diperoleh persamaan umum sebagai berikut:

$\mathrm{Y}^{\prime}=\mathrm{a}+\mathrm{bX}$

(Sugiyono, 2009: 270) 
Kepuasan Pelanggan $=18,510+0,504$ program service recovery

Konstanta sebesar 18,510 menyatakan bahwa jika tidak ada program service recovery, maka kepuasan pelanggan adalah 18,510. Koefisien regresi sebesar 0,504 menyatakan bahwa setiap penambahan (karena tanda+) 1 program service recovery akan bertambah sebesar 18,510. Hal ini menerangkan bahwa, program service recovery memiliki kontribusi terhadap tingkat kepuasan pelanggan yaitu sebesar 18,510.

Selain itu, diperoleh pula $t_{\text {hitung }}=9,466$ dan $\mathrm{t}_{\text {tabel }}=1,66$. Untuk memperoleh nilai $\mathrm{t}_{\text {tabel }}$ dengan menggunkan software SPSS (Statistical Product for Service Solution) 17,0 dan dibantu software microsoft excel (terlampir). Kaidah keputusan jika nilai $t_{\text {hitung }}>t_{\text {tabel }}$, yaitu 9,466 > 1,66, maka Ho ditolak dan Ha diterima, artinya program service recovery berpengaruh signifikan terhadap kepuasan pelanggan.

\section{Koefisien Determinasi}

Untuk mengetahui besarnya pengaruh variabel X terhadap variabel $\mathrm{Y}$, maka menurut Riduwan dan Sunarto (2010:81) digunakan rumus koefisien determinasi (KP) sebagai berikut:

$$
\begin{aligned}
\mathrm{KP} & =\mathrm{r}^{2} \times 100 \% \\
& =(0,691)^{2} \times 100 \% \\
& =0,478 \times 100 \% \\
& =47,8 \%
\end{aligned}
$$

Nilai tersebut dapat dilihat pula pada output koefisien korelasi pada lambang $\mathrm{R}$ square. Hasil perhitungan di atas menunjukkan bahwa besarnya KP (Koefisien determinasi) adalah $47,8 \%$ yang berarti bahwa perubahan variabel Y sebesar 47,8 \% dipengaruhi oleh variabel X. Dengan kata lain, 47,8 \% kepuasan pelanggan dipengaruhi oleh program service recovery, sedangkan $(100 \%-47,8 \%=52,2 \%)$ sisanya sebesar $52,2 \%$ dipengaruhi oleh faktorfaktor yang lain yaitu ; manajemen ekspektasi pelanggan, relationship marketing \&management, aftermarketing, strategi retensi pelanggan, superior customer service, technology infusion strategy, sistem penanganan komplain secara efektif.

Dari hasil pengujian hipotesis dapat diketahui bahwa terdapat pengaruh program service recovery terhadap kepuasan pelanggan. Usmara (2003:95) menyatakan bahwa "Terciptanya kepuasan pelanggan dapat memberikan beberapa manfaat, diantaranya hubungan perusahaan dengan pelanggan menjadi harmonis, memberikan dasar yang baik bagi pembelian ulang, dan terciptanya loyalitas pelanggan, dan memberikan rekomendasi dari mulut ke mulut (word of mouth) yang menguntungkan bagi perusahaan.

Hasil pengujian signifikansi koefisien korelasi serta uji-t menyatakan bahwa Ho ditolak, artinya terdapat pengaruh yang positif dan signifikan antara program service recovery yang terdiri dari meningkatkan ketelitian, mendengarkan keluhan, mengklarifikasikan bagaimana staf dapat bekerja apabila kata maaf tidak cukup, belajar dari kesalahan, menjadi proaktif dan meningkatkan kinerja, terhadap kepuasan. Hal tersebut sesuai dengan pendapat Fandy Tjiptono (2006:450) bahwa service recovery merupakan salah satu determinan kepuasan pelanggan.

Menurut Hoffman dan Kelley dalam Fandy Tjiptono (2006:465) Peranan service recovery dalam pemasaran jasa sangat krusial, kepuasan terhadap service recovery berkontribusi pada minat pembelian ulang, loyalitas dan komitmen pelanggan, trust, dan persepsi pelanggan terhadap keadilan atau fairness.

Menurut Johnston dalam Emma Andersson, et al, (2007:13) "Good recovery and complaint management have a positive impact on staff attitude and staff retention, process improvement, and create customer satisfaction." Artinya perbaikan yang bagus dan manajemen penanganan komplain memiliki dampak positif pada sikap karyawan, retensi karyawan, proses perbaikan, dan menciptakan kepuasan pelanggan.

Untuk menguji kelinieran, dapat digunakan uji F. Diperoleh nilai $F_{\text {hitung }}=89,605$, sedangkan $\mathrm{F}_{\text {tabel }}=3,09$ (terlampir), karena nilai $\mathrm{F}_{\text {hitung }}>$ $\mathrm{F}_{\text {tabel}}$, yaitu $89,605>3,09$, maka dapat disimpulkan Ho ditolak dan Ha diterima, artinya ada hubungan linier antara program service recovery dengan tingkat kepuasan pelanggan. Hal ini dapat dilihat dari tabel Sig. $=0,000$ yang lebih kecil dari taraf signifikansi $5 \%$.

\section{KESIMPULAN}

Berdasarkan hasil penelitian yang dilakukan oleh peneliti melalui analisis deskriptif dan verifikatif dengan menggunakan regresi liniear sederhana, maka berdasarkan 
penelitian tersebut dapat diambil kesimpulan sebagai berikut:

1. Pelaksanaan Program Service Recovery Kereta Api Argo Gede

Dimensi dari program service recovery yang paling tinggi skornya adalah meningkatkan ketelitian dibandingkan dengan mendengarkan keluhan, mengklarifikasikan bagaimana staf dapat bekerja apabila kata maaf tidak cukup, belajar dari kesalahan, menjadi proaktif, meningkatkan kinerja. Hal ini membuktikan bahwa Kereta Api selalu meningkatkan ketelitian dalam memberikan pelayanan kepada penumpang jika terjadi kegagalan jasa dengan cara kecermatan petugas dalam penanganan $\mathrm{AC}$, kecermatan petugas dalam penanganan kebersihan toilet, kecermatan petugas dalam penanganan kerusakan sarana. Dimensi dari program service recovery yang paling rendah adalah mengklarifikasikan bagaimana staf dapat bekerja apabila kata maaf tidak cukup.

2. Kepuasan Pelanggan

Skor tingkat harapan lebih besar dari pada tingkat kinerja yang dilakukan Kereta Api. Ini terbukti dari program service recovery yang diberikan, penumpang memiliki harapan yang lebih besar dibandingkan dengan kinerja yang dirasakannya.

3. Program service recovery yang terdiri dari meningkatkan ketelitian, mendengarkan keluhan, mengklarifikasikan bagaimana staf dapat bekerja apabila kata maaf tidak cukup, belajar dari kesalahan, menjadi proaktif dan meningkatkan kinerja berpengaruh sebesar $47,80 \%$ terhadap kepuasan pelanggan (Ho ditolak dan $\mathrm{Ha}$ diterima). sisanya sebesar 52,20\% dipengaruhi oleh faktor-faktor yang lain yaitu; manajemen ekspektasi pelanggan, relationship marketing\&management, aftermarketing, strategi retensi pelanggan, superior customer service, technology infusion strategy, sistem penanganan komplain secara efektif.

\section{DAFTAR PUSTAKA}

\section{Buku:}

Asep Hermawan, 2006. Kiat Praktis Menulis Skripsi, Tesis, Disertasi, Ghalia Indonesia, Jakarta.

Buchori Alma, 2007. Manajemen Pemasaran dan Pemasaran Jasa, Alfabeta, Bandung.

David W Cravens, 1996. Pemasaran Strategis, Erlangga, Jakarta.

Devi Puspitasari, 2006. Keamanan, Keselamatan dan Kesehatan Kerja SMK/MAK, Arya Duta, Jakarta.

Fandy Tjiptono, 2008. Manajemen Jasa, Andi Offset, Yogyakarta.

Fandy Tjiptono, 2009. Service Marketing Esesnsi dan Aplikasi, Marknesis, Yogyakarta.

Fandy Tjiptono, Chandra Gregorius dan Dadi Adriana, 2008. Pemasaran Stratejik, Andi Offset, Yogyakarta.

Freddy Rangkuti, 2006. Measuring Customer Satisfication, PT. Gramedia Pustaka Utama, Jakarta.

Furqon, 2009. Statistik Terapan untuk Penelitian, Alfabeta, Bandung.

Husein Umar, 2002. Metode Riset Bisnis, PT Gramedia Pustaka Utama, Jakarta.

J. Supranto, 2006. Pengukuran Tingkat Kepuasan Pelanggan Untuk Menaikkan Pangsa Pasar, Rineka Cipta, Jakarta.

Juhana Wijaya, 2001. Pelayanan Prima SMK Bisnis dan Manajemen, Armico, Bandung.

Kotler, Philip, 2000. Marketing Management, The Millenium Edition, Prentice- Hall, New Jersey.

Kottler dan Keller, 2009. Manajemen Pemasaran, PT Indeks Kelompok Media, Jakarta.

Kottler, Philip, 2005. Manajemen Pemasaran, PT Indeks Kelompok Media, Jakarta.

Kusnendi, 2008. Model-model Persamaan Struktural, Alfabeta, Bandung.

Lovelock, H. Christopher. Sevices Marketing : Text, Cases, and Reading, New Jersey: Prentice- Hall, 1984.

M.N. Nasution, 2008. Manajemen Transportasi, Ghalia Indonesia, Bogor.

Mardalis, 2003. Metode Penelitian Suatu Pendekatan Proposal, Bumi Aksara, Jakarta.

Mudie, Peter and Angela Cottam, 1993. The Management and Marketing of Services, Butterworth-Heinemann Ltd, Oxford. 
Rambat Lupiyoadi, A. Hamdani, 2008. Manajemen Pemasaran Jasa, Salemba empat, Jakarta.

Ratih Hurriyati, 2010. Bauran Pemasaran dan Loyalitas Konsumen, Alfabeta, Bandung.

Riduwan dan Sunarto, 2010. Pengantar Statistika, Alfabeta, Bandung.

Soejono dan Abdurrahman, 1999. Metode Penelitian Suatu Pemikiran dan Penelitian, Rineka Cipta, Jakarta.

Stanton, William J. (1991). Fundamentals of Marketing, 9th ed. Mc Graw Hill.

Sugiyono, 2008. Metode Penelitian Bisnis, Alfabeta, Bandung.

Suharsimi Arikunto, 2006. Prosedur Penelitian Suatu Pendekatan Praktik, Rineka Cipta, Jakarta.

Supramono dan Joni Oktavian H, 2005. Desain Proposal Penelitian Studi Pemasaran, Andi Offset, Yogyakarta.

Sutrisno Kusmawan Ruswandi, 2007. Melakukan Negosiasi, Yudhistira, Sukabumi.

Wahana Komputer, 2010. Mengolah Data Statistik Hasil Penelitian dengan SPSS 17. Andi Offset, Yogyakarta.

Walker, Jr at.al, 1992 Marketing Strategy : Planning and Implementation, International Student Edition. USA : D. Irwin Inc.

Wibowo, L. Adi Hand Out Metodologi Penelitian. Bandung.

Wina Sanjaya, 2008. Strategi Pembelajaran.

Kencana Prenada MediaGroup, Jakarta.

Literatur Majalah, Jurnal, Internet dan Sumber Lain

Betsy Bugg Holloway, Sijun Wang dan Janet Turner Parish, 2005. The Role of Cumulative Online Purchasing Experience in Service Recovery Management. Journal of Interactive Marketing Volume 19 / Number 3 / Summer 2005.

Majalah Parlementaria, Januari 2007

Parlementaria, januari 2009

Company Profile 2007 PT. Kereta Api Persero

Pedoman Penulisan Karya Ilmiah. (2009). Pedoman Penulisan Karya Ilmiah. Bandung: Universitas Pendidikan Indonesia
Zeithml, Valarie A., A. Parasuraman, and Leonard L. Barry. (1988). "Communication and Control Processes in the Delivery of Service Quality" Journal of Marketing, American Marketing Association.

Lewis, Barbara R., and Sotiris Spyrakopoulos. "Service Failures and Recovery in Retail Banking : the customer's perspective", International Journal of Bank Marketing, Vol. 19/2001 p.3447.

John Tschohl, "Loyal for Life: How to take Customer from Hell to Heaven in 60 seconds or less"

Gail Scott, 2009. Service Recovery, Healthcare Executive.

Irwin Press, Rodney F Ganey dan Melvin F Hall, 1997. What most important to customer satisfication's?, American Bankers Association. ABA Banking Journal.

Jovan Chia-Jung Hsu dan Chao-Min Hsu, Kun Shan University, Tainan, Taiwan, 2008. The Rekationship Between Srevice Quality and Customer Satisfication in a Leading.

Chinese Web 2.0 Company, The Business Review, Cambridge.

http://kereta-api.co.id/ 